\title{
OPINIE
}

\section{Toezichthouders moeten actief zijn op de sociale media}

Hans de Bruijn \& Dirk Janssen

\section{Hans de Bruijn: tegen}

Het spijt me, maar sociale media zijn nu eenmaal een habitat, waarin toezichthouders niet passen. Neem Twitter. Wat gebeurt daar? Dankzij Twitter heeft ieder individu zijn eigen zendstation, met een onbeperkt bereik. Natuurlijk, er zijn ook organisaties actief op Twitter - daarover straks - maar het primaat ligt toch bij individuen. Die twitteren waarover ze willen twitteren, over gebeurtenissen en opvattingen, over persoonlijke en zakelijke onderwerpen, over interesses en trivialiteiten - over alles dus. Dat maakt Twitter tot een levendige gemeenschap: je komt altijd wel iets verrassends tegen, moet soms hartelijk lachen en en passant leer je toch ook aardig wat. Ik volg Chris Buijink, de voormalig S-G van Economische Zaken en denk dat ik nu wat beter weet hoe een dag van een S-G eruitziet - en hij twittert altijd van die aardige foto's van zijn buitenlandse reizen. Ik volg prof. dr. Ewald Engelen, die iedere dag een aantal artikelen over de crisis twittert - en ik weet dat hij een Twentse collega een ONTZETTENDE LUL vindt [kapitalen van Ewald Engelen, HdB]. Ik volg Ouafa du Monceau, een Rotterdamse bestuurskundestudent van Marokkaanse origine, met werkelijk heel veel humor - en tussen de tweets door leer ik nog eens wat over een wereld die ik niet goed ken.

Verder: twitteren is volgen en gevolgd worden en dus is twitteren ook converseren. Je kunt het bijna niet maken om niet te reageren op je trouwe volgers met hun vragen en opmerkingen. En natuurlijk, dat zijn conversaties in alledaagse taal.

Er zijn ook organisaties actief op Twitter. Soms bieden die organisaties dankzij Twitter meerwaarde. Bedrijven die op grote schaal diensten aanbieden (banken, luchtvaartmaatschappijen) gebruiken Twitter om vragen te beantwoorden of klachten af te handelen - dat gaat sneller dan via de website. Onderzoeksinstellingen attenderen je op publicaties - en je kunt gelijk met de auteurs twitteren. Maar er zijn ook organisaties die meedoen op Twitter en geen enkele meerwaarde bieden ten opzichte van andere kanalen. Ze doen een eenzijdige mededeling, je kunt geen levendig gesprek met ze hebben. Als ze al reageren, is de reactie overduidelijk langs een communicatiedeskundige gegaan. Ik ben bang dat de meeste toezichthouders, met hun zwaar gejuridificeerde taken, tot die laatste categorie behoren. Als dit soort organisaties zich op Twitter meldt, komt dat bijna intrusive over - wel aanwezig zijn, maar niet echt meedoen. Wel aanwezig zijn, maar niet echt meedoen kan zelfs risicovol zijn: je bevestigt het beeld dat je een non- 
responsieve overheidsorganisatie bent - honderden boze tweets ontvangen en dan niet of formeel reageren, dat kan natuurlijk niet. En waar komt toch die obsessie met sociale media vandaan? Iedereen begrijpt dat er ook publieke organisaties zijn die, gegeven hun taken, een zekere distantie in hun DNA behoren te hebben. 'Gezocht: een saaie leider, die op de achtergrond functioneert', verzucht de New York Times rondom de zoektocht naar een nieuwe voorzitter van de Fed. Er zit iets in.

In de jaren zeventig kwam de Politieke Partij Radicalen op - de PPR. Het was een partij van jonge mensen die de wereld wilden verbeteren. Harry van Doorn was een prominent partijlid en minister in het kabinet-Den Uyl. Van Doorn leek in niets op het stereotiepe PPR-lid. Hij was op leeftijd en klassiek gekleed. Maar ja, op PPR-bijeenkomsten moest je je toch een beetje aanpassen aan de meer hippieachtige outfits van het gemiddelde PPR-lid. De cabaretier Wim Kan vond het potsierlijk. Harry van Doorn, zo zei Wim Kan, trekt op PPR-congressen een korte broek aan en vergeet zijn lange onderbroek uit te trekken. Dat is toch een beetje de toezichthouder op sociale media: meedoen met de nieuwste trend, maar in lange onderbroek.

\section{Dirk Janssen: voor}

Sociale media bieden nieuwe kansen en mogelijkheden, ook voor toezichthouders. Een moderne toezichthouder richt zich niet op de regeltjes maar wil onderliggende problemen aanpakken of, nog liever, voorkomen. In het belang van consumenten en bedrijven. Steeds meer consumenten en bedrijven begeven zich op sociale media. Dan kun je als toezichthouder niet achterblijven. Daarom is de Autoriteit Consument \& Markt actief op Twitter en Facebook.

Signalen zijn belangrijk voor ACM. Ze bepalen voor een groot deel de zaken die we oppakken. Ook via sociale media komen signalen binnen. Twitter biedt een laagdrempelige mogelijkheid om ons te tippen over mogelijke misstanden. Ik ben ex [...] medewerker en heb zelf waargenomen hoe prijsafspraken in de [...] tot stand komen. Medewerkers van ACM zaten dezelfde avond nog bij de afzender van deze tweet aan de keukentafel. Naast het signaleren van problemen, kunnen sociale media ook een onderdeel zijn van de oplossing. Nadat wij gereageerd hadden op een tweet dat een bepaald bedrijf spam zou verzenden, heeft het betrokken bedrijf contact gezocht met de boze ontvanger en hem direct van de maillijst gehaald. Zo kan het dus ook.

Je moet wel iets te bieden hebben via sociale media. Via ConsuWijzer helpt ACM consumenten hun recht te halen. 58 procent van de consumenten onderneemt actie na contact met ConsuWijzer. Consumenten kunnen ons bereiken via de telefoon, post, e-mail én sociale media. Via Facebook en Twitter krijgen wij vragen binnen en geven wij gratis advies op maat. Door te verwijzen naar bestaande content of een voorbeeldbrief op ConsuWijzer. Een consument helpen via sociale media heeft ook voordelen voor ACM. Een antwoord via sociale media heeft een groter bereik dan via een brief of tijdens een telefoongesprek. Bovendien kan een consument via sociale media zijn verhaal verder verspreiden. Een op de acht 
Nederlanders is inmiddels actief op Twitter. Dit betekent dat er een enorm potentieel aan individuele 'toezichthouders' is dat ons kan helpen bij onze taak. Het signaleren van problemen, het geven van voorlichting en waarschuwen voor misleiding is niet louter meer het exclusieve domein van een toezichthouder.

Een toezichthouder is onafhankelijk. Maar 'independence does not equal isolation', aldus Bill Kovacic, oud-voorzitter van de Federal Trade Commission. Je bent onafhankelijk in de beslissingen die je neemt, maar dat wil niet zeggen dat je dit vanuit je ivoren toren doet. ACM moet consumenten en bedrijven in duidelijke taal kunnen uitleggen wat ons bezighoudt. Daar zijn sociale media bij uitstek een goed middel voor. Maar het gaat niet alleen om uitleggen, maar ook om discussie. Collega-toezichthouder AFM consulteert al geregeld zijn achterban via LinkedIn. Een win-winsituatie voor zowel stakeholders, die op toegankelijke wijze hun input kunnen geven als voor toezichtmedewerkers. Want door medewerkers te stimuleren actief te zijn op sociale media, blijven ze scherp voor de behoeften en vragen van de buitenwereld. Nog mooier zou zijn als toezichthouders meer naar buiten durven te treden over de vragen waar ze zelf mee worstelen. Toezicht is niet zwart-wit, en draait om keuzes en dilemma's. Dus waarom zou je niet, waar het kan, deze keuzes via sociale media voorleggen aan het publiek? Nog maar weinig toezichthouders doen dit daadwerkelijk. Ook ACM niet. Welke toezichthouder durft te vragen? \#dtv 